Inna Povorozniuk, Candidate of Economic Science, Associate Professor, Pavlo Tychyna Uman State Pedagogical University, 2, Sadovastr., Uman, 20300, Ukraine, ORCID: 0000-0002-2575-5114; ResearcherID: D-6771-2019

\title{
FORMATION OF SUSTAINABLE TOURISM DEVELOPMENT STRATEGY OF THE REGIONS OF UKRAINE
}

The article deals with the theoretical and methodological principles of sustainable tourism development in the region and substantiation of directions of increasing its efficiency and functioning in the conditions of economic management. It is proved that not every region can be considered tourist, because every tourist region of our country has its own set of specific characteristics and problems of its development. They differ in economic, natural, socio-political, demographic and other factors. Accordingly, their clear distribution on specific features will allow to develop bases of territory marketing and to formulate effective approaches to territorial positioning and formation of tourist region image.

To do so requires distinguishing the criteria by which we can consider whether this or that region is tourist. However, choosing a priority sector for the region requires at least the adequate assessment of the sector's contribution to GDP growth, as well as the assessment of its prospects.

Different approaches to assessing tourism development at the regional level should be used. However, despite the large number of publications on this topic, most authors are limited to either merely a target setting or describing mathematical models without going directly to the calculations themselves. To our opinion, this is explained by the lack of statistical information that is already needed directly for the calculations and also contains methodological errors.

The value of this result for the practice of state and regional government, in our view, is low. The simple calculation of the aggregate income from tourism, taking into account the multiplier effect, only illustrates the importance of this economic sector for the region. Therefore, we need other information obtained from the marketing analysis of this regional market.

Keywords. Tourism, tourist region, tourist and recreational complex, strategy, tourist infrastructure. 


\section{Relevance of research topic.}

In recent years the role of tourism in the economy has increased significantly. This is confirmed by the statistics of a number of national and international organizations. Despite all the negative forecasts, even the global financial and economic crisis has not seriously affected the global tourist flows.

At the beginning of the 21 st century, tourism became one of the leading areas of socio-economic, cultural and political activity in most countries and regions of the world. Tourism plays an important role in strengthening international ties between the seven billion people of the planet: about one billion people visit other countries each year for tourism purposes. According to the World Tourism Organization's forecast «Tourism 2020 Vision», the number of international trips will reach 1.6 billion by 2020 , with $4 \%$ annual growth in world tourism [6].

Considering tourism as a system of natural, historical, cultural, political, economic, social and other components that are interconnected and aimed at meeting human needs for recreation, it is necessary to understand the mechanisms governing the development of tourism.

Therefore, in the current conditions of globalization and fierce competition, the issues of rational resources use and development regional centres of economic growth on the basis of innovative approaches become urgent. For the regions of Ukraine, the rational use of tourist and recreational resources is of strategic importance on the basis of a clear strategy of sustainable tourism development.

Therefore, the study of the formation of the sustainable tourism development strategy in the regions of Ukraine is relevant.

Analysis of recent research and publications. Many works of Ukrainian and foreign scientists are devoted to the research on tourism activity development and strategy, in particular: N. Vyhovska, I. Saukh (2018), V. Kifiak (2015), N. Korzh, D. Basiuk (2018), O. Savitska, N. Savitska (2017), O. Trokhymets, T. Shelemetieva (2018), V. Prokhorova, O. Davydova, and V. Protsenko (2018), A. Kazak, (2018), A. Dorofeieva (2018), Adrian-Liviu Scutariu, Carmen Nastase and Mihai Popescu (2016), Xavier Font, James Higham, Graham Miller and Shahab Pourfakhimi (2019).

However, despite the scientific value and importance of the works, it is not enough to cover the issue of forming a strategy for sustainable tourism development in the regions of Ukraine. This determines the relevance and importance of the chosen topic of the research.

\section{Formulation of the problem.}

To study the theoretical and methodological principles of sustainable tourism development in the regions and to justify the directions of increasing its efficiency and functioning in market conditions. 


\section{Presenting main material}

According to the results of 2018, the total revenues of the tourist tax and tax payments from the tourist industry in Ukraine increased by $20.7 \%$ - up to 4.2 billion $\mathrm{UAH}$, the tourist tax revenues increased by $29.2 \%$ and amounted to 90.7 million UAH.

In 2018, the State Border Service recorded the increase in the number of tourists from non-border countries, including Europe: Spain - by 68\%, the United Kingdom $47.3 \%$, Lithuania $-23.4 \%$, Italy $-15.4 \%$, Germany $-13.3 \%$, France $-9.2 \%$, India $57.4 \%$, China $-38.8 \%$, Japan $-38.3 \%$, Israel $-21.7 \%$ and the United States $-19 \%$. The border traffic on the contrary declined.

Such changes in the tourist flow structure were the result of intensified promotion of Ukraine at the international tourism market, bilateral cooperation, visa liberalization, increase in offers of direct and budget air services.

According to the data of Ukrainian mobile operators (PJSC «Kyivstar», PJSC «VF Ukraine», LLC «Lifesell»), 162.2 million movements of mobile subscribers by Ukraine were recorded in 2018, of which 139.8 million were Ukrainian and 22,3 million - foreign citizens.

The Transcarpathian, Odesa, and Kharkiv (acquiring the role of business tourism center) regions are the most popular for foreigners to visit. Ukrainians mostly visit Kyiv, Lviv, Poltava, Cherkasy and Dnipropetrovsk regions [10].

For the successful development of tourism, the government plans to create a central executive body in 2020 that will oversee the hospitality industry and promote Ukrainian tourism in the world. The form of such a body is a state agency. In 2011, the Ukraine State Agency for Tourism and Resorts was established in Ukraine. In January 2015 the agency was liquidated and after that the functions of ensuring public policy in tourism began to be performed by the Department of Tourism and Resorts at the Ministry of Economic Development and Trade.

Also, for the first time in the history of Ukraine in the draft budget for tourism development 240 million UAH are planned for 2020. «It is ten times as much as it was last year», wrote Oleksandr Liiev, the Head of the Hospitality Industry Association. These funds will be used for the domestic tourism development, the creation of tourist infrastructure, the promotion of Ukrainian tourism products in the world and the enhancement of the tourist service level in Ukraine. In 2018 tourist revenues in Ukraine have increased by almost a third [10].

To organize tourism as a type of activity requires a comprehensive approach, the form of which implementation is a tourist recreational complex. Its formation is directly related to the socio-economic development of economic entities of tourism infrastructure in the current environmental conditions.

The tourist recreational complex is a complex of interconnected industries that provide the implementation of tourist activity in Ukraine. 
The tourist recreational complex development depends on two components: first, all tourist and recreational resources that are fundamental in planning or forming a package of tourist product, and second, fully from the developed social and economic infrastructure of tourist and recreational tourist services.

The social and economic system of the region forms a single tourist and recreational space, the elements of which are the natural environment; historical and cultural monuments; placement facilities; catering companies; entertainment and sports facilities; travel agencies; trade enterprises; transport, financial, information, social infrastructure etc.

It should be noted that not every region can be considered a tourist destination. For this purpose, it is necessary to distinguish the criteria by which we can consider whether this or that region is tourist.

Each tourist region of our country has its own set of specific characteristics and problems of their development. They differ in economic, natural, socio-political, demographic and other factors. Accordingly, their clear distribution on specific features will allow to develop the territory marketing principles and to formulate effective approaches to territorial positioning and formation of tourist region image.

Thus, E.A. Dzhandzhugazova classifies the typology of regions by the following factors [2, c. 38-39].

By the economic development level:

- highly developed regions;

- developing regions;

- underdeveloped regions.

By the current state of the economy, finance, social sphere and environment:

- successfully developed regions that have adopted a market-based economic model;

- crisis regions where some critical industries are located;

- depressed regions where the economic complex or selected industries are depressed.

By the natural geographical or geopolitical characteristics:

- extreme and natural climatic zones;

- coastal regions;

- border regions.

- regions remote from the main territory of the country.

According to the author the typology of regions will allow to build an effective regional policy, to assess the opportunities of the region, as well as its development weaknesses more accurately.

In order to make effective management decisions, it is necessary to distinguish the tactical and strategic typology of the regions.

The tactical typology highlights: 
- «supporting» or well-developed regions, mainly from an economic point of view;

- «self-sufficient» regions (taking into account the regions that form market relations);

- «financially stable» regions;

- «unstable» regions (above all, in terms of social and economic development).

The strategic typology includes:

- old industrial regions;

- transitional regions;

- developing regions.

The author also notes that it is necessary to conduct a typology of regions and to identify the main directions of state regulation of regional development. There are four types of regions:

- traditionally backward regions;

- depressive regions;

- traditionally developed (industrial, recreational, agrarian and other) regions;

- regions that have resources of national importance [2, c. 39].

The tourist and recreational complex functions not in isolation but in close relationship with other structural elements in the system of regional economy. Its development is linked in many ways to many types of economic activity, because the growth of the shopping and entertainment industry necessitates corresponding transformations in retail trade, public catering, passenger transport, domestic services etc.

The tourist and recreational complex of the region is a set of economic relations between its main participants in order to generate demand and supply of tourist services. It is a collection of industries and services for the population, where investment resources are focused on the economic and social efficiency increase, which is expressed in meeting the needs and maintaining the health and earning capacity of the citizens.

On the basis of this definition, we can distinguish the outstanding characteristics of tourism:

- a special meso-level entity;

- an object of state economic management for the purpose of social policy implementation, which provides support for human life and life sustenance;

- a sphere where investment funds serve as a resource for the industries and services that are part of the tourist and recreational complex;

- a scope of investment resources allocation to increase their primary value (participation in real investment). The development of the tourist recreational complex is able to provide: formation of conditions for investment activity intensification in the industries and services of the market space of the region, which are part of the tourist recreational complex and ensuring economic growth on the basis of the investment component;

- an inflow of Ukrainian and foreign investments into the region; 
- transformation of population savings into investments;

- redistribution of temporary free money of the consumer, industrial and financial complex of the region and funds coming from other sources, investment resources aimed at preservation and reproduction of the historical and cultural heritage of the territory, formation of additional objects and interests of tourists.

The structure of the complex includes elements each of which performs a specific function according to the purpose of the whole system. These elements include the following components: service consumers (tourists), tourist resources (natural and cultural-historical etc.), establishments providing tourist services, tourist infrastructure (food, accommodation, transportation) and organization and management bodies (travel agents, tour operators).

The main purpose of the tourist and recreation complex is to create a tourist product to meet consumer demand.

The tourist product created in the tourist recreation complex is formed according to tourist resources.

The structure of tourist recreation complex is investigated in three aspects: functional, territorial (spatial) and organizational-managerial.

In Ukraine, while developing tourism development programs, although regional features are taken into account, they are focused on problems rather than development prospects. The main emphasis should be placed not only on the need for the formation and development of the tourist and recreational complex, taking into account the needs of the population, but also in the light of their capabilities. The study of market mechanisms for the functioning and development of the tourist recreation complex, and in particular the account of its territorial belonging, must necessarily be combined with the state economic policy.

Like any complex system planning of the tourism industry development requires quantitative and qualitative assessments, studying the regularities of their functioning, which can be obtained on the basis of a complex of mathematical models.

The mathematical modelling use allows making predictions in the complex systems and making effective management decisions regarding the choice of paths for further development. Conditionally, the scheme of implementation of the strategy of sustainable tourism development can be seen in figure 1 .

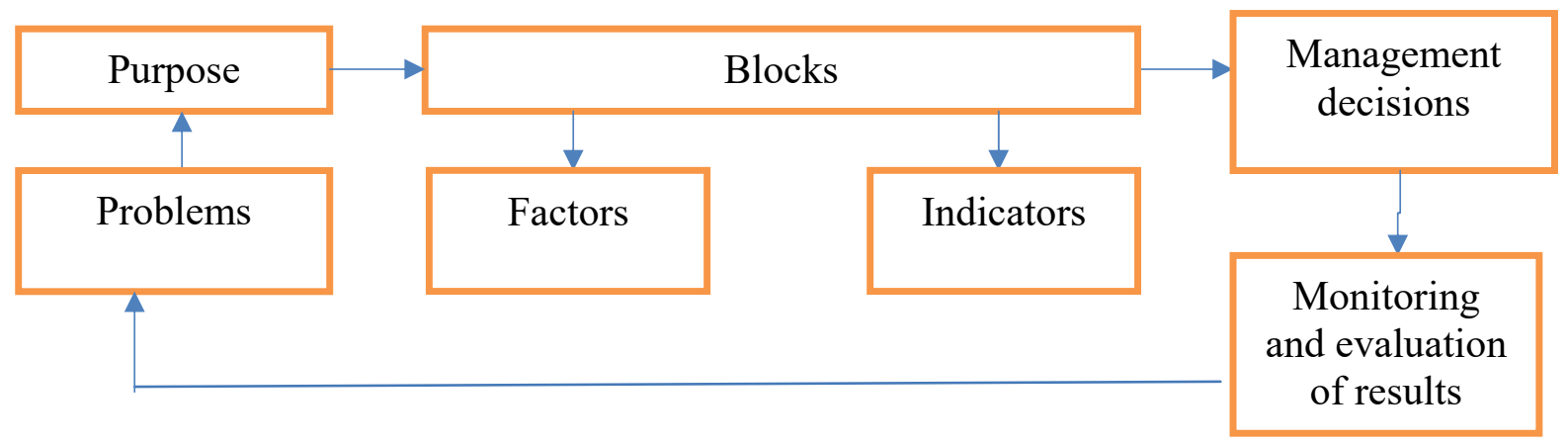

Figure 1. Scheme of sustainable development strategy implementation 
Sustainable tourism development implies development in the conditions of economic, ecological and social stability. Each block has factors that determine its development and indicators that characterize them. Factors and indicators must be formed for each individual region.

In developing a tourism strategy, local authorities, communities and businesses should form the mechanisms for coordinating their actions with the ministries responsible for environment, energy, labour, agriculture, transport, health, finance, security etc. Clear requirements must be laid down for: zoning, territory protection, environmental protection, labour law, agricultural standards, health care, energy supply, emissions, water supply, waste and sanitary standards.

Defining a tourism strategy means moving in one direction. The main task is to professionally show a real picture of the region and to cooperate with the relevant service providers.

One of the main parts of the strategy development is its priority areas.

1. Policy development, organization of structure and creation of the legislative base on tourism: approval of the policy of local and regional tourism development plan as a single document; assistance in the development of a regional centre or travel agency to raise capital in the tourism industry; strengthening the regulatory framework for tourism to ensure appropriate standards; organization of network centres throughout the region to advise on tourism programs.

2. Staff development and training.

3. Partnership development programs: involving local people in tourism development and making integrated tourism development plans, including all infrastructure elements to prevent unmanaged development; effective public and private sector organization and support for close cooperation between public, private and state organizations in the region in which they are involved; building partnerships for special areas to ensure the year-round work of the region sights.

4. Environmental protection support, protection of resources: support for the development of ecotourism, national parks, reserves and rural areas; environmental protection measures; development standards (legal framework for the development of the region) and the development of directives for tourist sites.

5. Development of infrastructure and attraction of investments in tourism: development of regional transport system, including roads, railways depending on tourism needs; expanding the system for collecting, analysing and widening statistics and regular marketing research to attract investment and help with decision making; introduction of mechanisms and subsidies for attracting investments from local and foreign investors; identifying investment opportunities and taking measures to extend the tourist season in the region; increasing public funding for the development of tourist facilities and infrastructure; effective and systematic financing of individual tourism projects. 
6. Development, diversification and promotion of tourist offers: information services; creation of a coordinated network of tourist information centres in all major tourist regions to improve the provision of hospitality to guests, providing them with accurate information that helps them navigate and enjoy themselves in the tourist area; organization of tourist routes.

7. Marketing directions: creation of a regional database of products, objects, events and services, both for the tourism industry and for public access; development of the tourist internet portal of the area as the main tool for promoting, informing and organizing meetings; creation and promotion of a database of cultural events in the region in the tourist market.

For the first time, the term sustainable development was introduced by the UN in 1972 and was used to emphasize the need for appropriate action in development projects. The main concept of sustainable tourism development is meeting the needs of tourists and the public, as well as protecting tourist sites as part of the country's economic resources. Tourism should improve the life quality of the local population through the protection of the environment [6].

Many Ukrainian regions today highlight tourism as a priority sector of the economy. However, choosing a priority sector for the region requires at least an adequate assessment of the sector's contribution to GDP growth, as well as an assessment of its prospects.

There are two approaches to assessing the impact of tourism on the economy of a country or region. The first one uses the accounts of tourism satellites, which provide an analysis of demand in the tourism sector. This approach has become widespread in foreign practice and is used by statistical organizations in many countries. The second approach is based on economic calculations and involves the calculation of a tourist multiplier derived from the Keynesian macroeconomic model.

The essence of the multiplier effect is that the increase in expenditures leads to an increase in the national income of the society by an amount greater than the initial increase in expenditures. Satellite accounts are currently not used in Ukrainian statistics, so tourism professionals are choosing the second approach when solving the problem of assessing the impact of tourism on the economy. Different types of multipliers are used in the calculations, namely: income multiplier, tax multiplier, employment multiplier.

Recently, attempts have been made to use different approaches to assessing tourism development at the regional level. However, despite the large number of publications on this topic, most authors are limited to either merely stating a problem or describing mathematical models without going directly to the calculations themselves. In our view, this is explained by the lack of statistical information that is already needed directly for the calculations and also contains methodological errors. 
The value of this result for the practice of state and regional government, in our opinion, is low. The simple calculation of the aggregate income from tourism, taking into account the multiplier effect, only illustrates the importance of this sector of the economy for the region.

Therefore, we need other information obtained from the marketing analysis of this regional market (figure 2).

In particular, in order to implement public policy, it is advisable to use not a single integral indicator (aggregate tourism income) but a whole system of indicators related to the assessment:

- total tourist flow and factors affecting its value;

- spatial distribution of tourist flows in the region;

- the magnitude of tourism expenditures: basic and additional;

- share of tourism expenditures related to the purchase of locally produced services and goods;

- tax payments to the regional budget;

- the extent and role of the unregistered supply in the tourist services market;

- employment: basic and seasonal, legal and illegal.

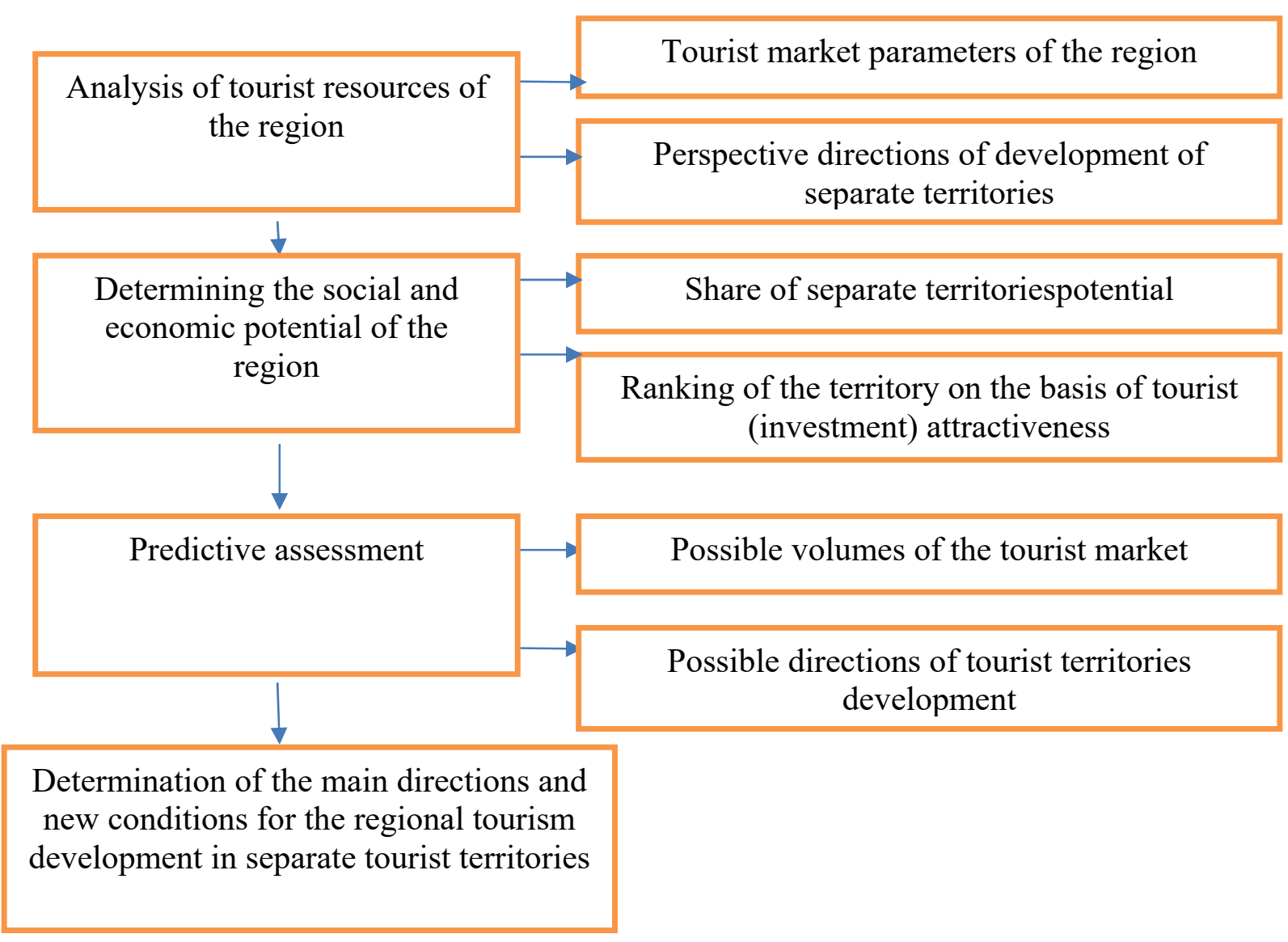

Figure 2. Sequence of marketing analysis of tourist areas 
Thus, the survey should include: analysis of official statistical information; experience of tourism business representatives.

In order to implement this stage, a detailed plan for the marketing and promotion of the tourism sector should be developed, taking into account the quality and quantity of tourism products, the diversity of domestic, regional and international priority markets, image and positioning, branding, quality, ways of marketing materials distribution (including e-marketing) and legal marketing mechanisms, including partnerships between the private and public sectors. It is necessary to evaluate the strategic positioning of the region/locality as a tourist destination, to determine the benefits of the region.

The mechanism for improving the key parameters of the region's domestic tourism market is to determine its status, potential opportunities and main directions of development. As a key parameter, it is advisable to highlight the level of socioeconomic attractiveness of a tourist territory within the region, which is inseparably linked to investment attractiveness.

The effective realization of the tourism potential of the region in modern conditions is hampered by the number of unresolved problems and complexities of organizational, regulatory, scientific, technical, industrial and financial nature.

Among them the most important are: insufficient development of tourist infrastructure, in particular: insufficient level of the hotel complex development, as well as relatively weak (in comparison with the world) level of development of the complex of services, regional transport system: railway, river, air and road; unsatisfactory condition of a large number of tourist sites.

According to the World Tourism Organization, infrastructure is a major factor in tourism development. Tourists spend only a small part of their budget on sights. The main costs of tourists are transport, accommodation, food, shopping and leisure.

When developing tourism, it is necessary to be aware of the commercial realities of your region: how to rationally stimulate the tourist expenditures increase for the benefit of your facility and the local population.

Conclusions. Thus, from the point of view of maximizing the tourism potential of the territory, it is necessary to focus more attention on the investment aspect of tourist activity in the region and to develop the infrastructure of the region in view of the strategic and operational goals of the Regional Development Strategy, as it should promote regional tourism and expand the municipal housing programs, develop and support small and medium-sized businesses, create a favourable investment climate for priority areas of development of the region together with the trends systems such as education and medicine. At the same time, it is very important to attract external resources through projects, in particular financing infrastructure projects from the State Regional Development Fund. 
The active attraction of investments in the territorial management practice could make a significant contribution to the infrastructure development of the tourism industry of the regions. Its diversity (by priority and volume of investment) is determined by the natural-geographical, socio-economic and other regional factors, but it is possible to create typical variants of investment activity in the regions, taking into account the status and tendencies of tourist potential development of the territory.

In addition, the regional tourism industry is so multifaceted that it requires the use of a variety of information technologies, ranging from the development of specialized software that provide automation of the work of an individual tourist company or hotel, to the use of global computer networks.

An important condition for creating a well-functioning management system of investment processes in the tourism industry is improving the scientific validity of managerial decisions in the field of investment, ensuring the interaction of such basic elements of the management system as principles, methods, management functions, tools, orienting the implementation of investment projects to achieve the required results and efficiency level. These circumstances necessitate the formation of such a mechanism for managing the process of investing funds in the regional tourism business, which would ensure the achievement of the set goals of investment planning in a strategic aspect.

\section{REFERENCES}

1. Vyhovska, N., Saukh, I., (2018). «Stratehichnyi rozvytok turystychnoi haluzi v Zhytomyrskii oblasti». VISNYK ZhDTU. Finansy i statystyka. 2018. № 2 (84) pp.118-124.

2. Djandjugazova, E. (2019). Marketingovyie tehnologii v turizme: marketing turistskih teritoriy: ucheb. posobie dlya SPO. M.: Izdatelstvo YUrayt, 208 p.

3. Kyfiak, V. «Rozvytok turyzmu yak odyn zi stsenariiv pokrashchennia sotsialno-ekonomichnoho stanu Chernivetskoi oblasti». Visnyk Chernivetskoho torhovelno-ekonomichnoho instytutu. Ekonomichni nauky. 2015. Vyp. 2. pp. 67-81, available at: http://nbuv.gov.ua/UJRN/Vchtei_2015_2_9 (Accessed 19

February 2020).

4. Korzh, N., Basiuk, D. (2017). Upravlinnia turystychnymy destynatsiiamy [Management of tourist destinations], Vinnytsia, «PP»TD Edelveis i K», available at: http://www.oridu.odessa.ua/7/7/ metoduchni-rek/t/04.pdf (Accessed 20 February 2020).

5. Melnychenko, O., Shvedun, V. (2017). Osoblyvosti rozvytku industrii turyzmu $\mathrm{v}$ Ukraini: monohrafiia. Kharkiv: Vyd-vo NUTsZU, available at: http://repositsc.nuczu.edu.ua/bitstream/123456789/2195/1/\%D0\%9C\%D0\%BE\%D0\% BD\%D0\%BE\%D0\%B3\%D1\%80\%D0\%B0\%D1\%84\%D0\%B8\%D1\%8F_\%D0\%9C\% 
D0\%B5\%D0\%BB\%D1\%8C\%D0\%BD\%D0\%B8\%D1\%87\%D0\%B5\%D0\%BD\%D0 $\%$ BA $\%$ D0\%BE $\% 2$ C $\% 20 \%$ D0\%A8\%D0\%B2\%D0\%B5\%D0\%B4\%D1\%83\%D0\%BD 2017.pdf(Accessed 20 February 2020).

6. Ofitsiinyi sait Vsesvitnoi turystychnoi orhanizatsii, available at: http://www2.unwto.org/en (Accessed 22 February 2020).

7. Prokhorova, V., Davydova, O., Protsenko, V. (2018). Innovatsiini stratehii rozvytku pidpryiemstv turystychnoi industrii yak kreatyvna forma orhanizatsii pidpryiemnytskoi diialnosti. Visnyk ekonomiky transportu i promyslovosti, № 63 . pp. $207-215$.

8. Savitska, O., Savitska, N., Pohrebniak, L. (2017), «Ecotourism as an important component of the strategy of sustainable development of Ukraine», Hlobalni ta natsionalni problemy ekonomiky, no. 15, pp. 122-128.

9. Savitska, O., Savitska, N. (2017), «Stratehiia rozvytku turystychnoi industrii v Ukraini: rehionalni aspekty», available at: file://C:/Documents $\% 20 \mathrm{and} \% 20$ Settings/User/\%D0\%9C\%D0\%BE\%D0\%B8\%20\%D0\%B4\%D0\%BE\%D0\%BA\% D1\%83\%D0\%BC\%D0\%B5\%D0\%BD\%D1\%82\%D1\%8B/Downloads/VNULPP 2013_754_12.pdf (Accessed 20 February 2020).

10. U 2018 rotsi dokhody vid turyzmu v Ukraini zrosly maizhe na tretynu: vebsait, available at: https://zik.ua/news/2019/02/21/u_2018_rotsi_dohody_vid_turyzmu_ v_ukraini_zrosly_mayzhe_na_tretynu_mert_1514507 (Accessed 22 February 2020).

11. On approval of the Tourism Development and Resorts Strategy for the period up to 2026, available at: https://www.kmu.gov.ua/ua/npas/249826501 (Accessed 20 February 2020).

12. Trokhymets, O., Shelemetieva, T. (2018). Praktyka stratehichnoho planuvannia v systemi upravlinnia rozvytkom turyzmu v Ukraini. Derzhava ta rehiony. Seriia: Ekonomika ta pidpryiemnytstvo, № 4 (103). pp.70-78

13. Dorofeeva, A. (2018). Simulation of Advertising Activity in Tourist Business. Quality Management Transport and Information Security Information Technologies (IT\&QM\&IS) 2018 IEEE International Conference. pp. 836-838.

14. Adrian-Liviu Scutariu, Carmen Nastase and Mihai Popescu, (2016). Perspectives of Sustainable Development of Tourism in the North-East Region of Romania. Sustainability, MDPI, Open Access Journal, vol. 9(1), pp. 1-14, December.

15. Kazak, A. (2018). Analysis of Dynamics of Demand Revenue and Ergonomic Aspects of Tourism. Human Factors in Complex Technical Systems and Environments (ERGO) 2018 Third International Conference on, pp. 13-15.

16. Xavier Font, James Higham, Graham Miller, and Shahab Pourfakhimi (2019). Journal of Sustainable. Tourism, Volume 27, Issue 1. pp. 1-11. 